\title{
Factors Influencing Establishment of Neem Plantations in Southern Tamil Nadu, India
}

\author{
A. Divakaran ${ }^{1 *}$, C. Sekhar ${ }^{1}$ and P. Balajji ${ }^{2}$ \\ ${ }^{1}$ Department of Agricultural Economics, ${ }^{2}$ Department of Agricultural and Rural Management, \\ TNAU, Coimbatore - 641 003, India \\ *Corresponding author
}

\section{A B S T R A C T}

\section{Keywords}

Neem, Economic Potential of neem, Net present value, Internal rate of return

\section{Article Info}

Accepted:

12 October 2019

Available Online:

10 November 2019
Neem declared as the tree of $21^{\text {st }}$ century by United Nations. Neem plantation in agro - forestry will strengthen social and economic status of the rural households. Collection of Neem seeds and leaves are the important means of supplementary employment and extra income for the rural households particularly the rural women. Neem products are used in multiple uses and hence it has great demand. Because of this, the farmers are interested in establishing Neem Plantations in their farm holdings. Neem is highly profitable according to economic parameters and capable of generating highest Internal Rate of Return. The cost of Neem seed collection per $\mathrm{kg}$ is arrived at Rs three and the selling price is around $38 \mathrm{per} \mathrm{kg}$ on provision of quality seeds and hence certain seed collectors pay special attention on maintaining the quality to get a higher price per unit of Neem seeds. On an average, a Neem tree could yield $58 \mathrm{~kg}$ of seeds and in a ha area, the plantation can provide a yield of 11.75 tonnes of Neem seeds. Considering the economic potentials filled with Neem, higher area is visualized in the study environment in the future years. Price per unit of Neem seeds found to be the principal factor in influencing the Neem seed collection.

\section{Introduction}

Neem tree has become an important tree in the global context today because it offers answers to the major concerns facing mankind. Such a wonderful tree belongs to the family of Meliaceae which is native to dry forests of South and Southeast Asia. Neem and its products are considered to be harmless and hence the same has been approved by the United States' Environmental Protection Agency for use as food crops.From the primeval times, Neem has been a noteworthy common tree species in India due to its multifunctional uses like Medicinal, Biofertilizer, Fumigant, Bio-Pesticides, Oil Seeds and Cattle Feed with various ecological and environmental benefits (Lokanadhan et al., 
2012). The sixth World Neem Conference which was held in Nagpur during 2012 also predominantly focused on the utilization aspects of Neem but its cultivation and development of value chain mechanisms through agroforestry and urban forestry was not much addressed and needs momentum. There are various Neem based agroforestry systems are observed in India. They are AgriSilviculture, Agri-Silvi-Horticulture, SilviPastoral systems and shelter belts / windbreaks etc. Neem based agroforestry systems are not put into focused research specifically on socio-economic aspects of establishing Neem plantations in the farm lands. The Neem trees available in the common lands like roadsides, poromboke lands, ponds, tanks etc. become threatened due to its multifunctional uses and small timbers. Increased Brick Kilns in the city environment quite naturally provide a threat to Neem Plantations also and they were extracted as fuel wood to the Brick Kiln. Amidst all these threats, the farming community of Virudhunagar and Thoothukkudi Districts had shown much interest in establishing these plantations in their farm lands with a 20 to 25 year rotation period. Such a wonderful and multipurpose Neem tree and its cultivation were influenced by certain factors. This study was specifically initiated to address the factors which are influencing the Cultivation of Neem Trees particularly in Southern Tamil Nadu because they are the leaders in Tamil Nadu in respect of establishing Neem plantations with the objective of assessing the economic incentives contributed by the trees.

\section{Design of the Study}

In Tamil Nadu, only 5 districts stand above 100 ha of area under Neem tree. Among the 5 Districts, Virudhunagar and Thoothukkudi Districts stands first and second position respectively. Virudhunagar District as it stands first in respect of area under Neem, the researcher has chosen the district for conducting the study. Besides the area, Oil Mills were available in plenty in Madurai District and hence the Virudhunagar and Madurai Districts were purposively chosen in the First Stage.

After selecting the districts, the blocks which are having higher area under Neem were accessed by contacting the Department of Agriculture officials available in Virudhunagar District and the following blocks were selected.

The selected blocks are Sivakasi blessed with 151 ha under Neem, Vembakottai block is in possession of 126 ha, Virudhunagar block is occupied with 118 ha, Sattur block is having an area of 73 ha and the Kariapatti block is having an area of 64 ha and hence these five blocks were purposively chosen in the Second Stage as these blocks were enriched with higher area under Neem plantations.

In the Third Stage, different population of Neem cultivating farmers was visible and hence the researcher has resorted to the proportionate sampling with 10 per cent for having quick survey. In this respect, around 20 farmers whom have raised Neem plantations were selected by practicing proportionate sampling.

Since our study is focusing on economic incentives associated with the Neem plantations, the importance of collection of Neem seeds become much more important to the researcher on account of sustainable output and hence the researcher has resorted the practice of choosing the Neem Seed Collectors (NSC) following simple random sampling technique in different villages under each block and hence who ever are collecting the Neem seeds in the morning hours have been contacted and are interviewed to assess the practices followed in Neem seed collection, processing and sales to the retailing or 
wholesaling units of both Virudhunagar and Madurai Districts forming a total sample of 100. These details are presented in Table 1. Since the study focuses on assessing the economic incentives associated with the Neem plantations and the factors which are motivating the farmers to establish the Neem plantations in a larger scale, the following tools of analysis resorted to develop feasible information on Neem plantations which will be helpful to the other farmers in different zone will be in a position to practice the same.

\section{Tools of analysis}

\section{Percentage analysis}

To analyze the economic incentives, one has to concentrate on annual costs involved in respect of Neem plantations through appropriate structured questionnaire for collecting the data. For that purpose, the questionnaire available with the Comprehensive Scheme on Cost of Cultivation of Principal Crops funded by Government of India and operated in the Department of Agricultural Economics was also resorted to.

\section{Cost analysis for neem}

In respect of cost analysis for Neem, the costs were classified into three different categories viz. Establishment Cost; Operational and Maintenance Cost; Harvesting and PostHarvest Management Cost.

\section{Establishment cost}

The establishment cost or the cost incurred in the zero-time period comprise rental value of land, cost of planting materials, cost of farm house or store house, expenditure on farm equipment, fencing and investment on planting Neem seedlings. The sum of all these costs are termed as Establishment Cost.
Similar approach is practiced by Sekhar (1995) and Rithambhara Singh during 2017.

\section{Operational and maintenance cost}

After incurring the establishment cost, the farmer is required to make some more investments until the tree reaches the bearing stage.

Such costs are known as operational and maintenance cost mainly incurred for land preparation, manures and manuring, channel and basin formation, fertilizer application, pesticide use, irrigation and the human labor used for different operations to maintain the plantations are accessed from different farm households having different age group of Neem plantations in the study environment and are presented for twenty years.

Repeated questions were imposed to the farmer on the vague answer and confirmed the data with regard to its validity.

\section{Harvesting and distribution cost}

The harvesting and distribution cost which included harvesting cost, packing charges, grading charges, transportation charges, loading and unloading cost. Similar methodology was practiced by Rithambhara Singh during the year 2017.

\section{Benefit cost ratio}

This is another indicator used to test the worthiness of investment. It is the ratio of sum of discounted net benefits to the sum of discounted capital costs. It is expressed as follows

B. C. Ratio $=\frac{\sum_{i=1}^{n} \frac{B_{n}}{(1+i)^{n}}}{\sum_{i=1}^{n} \frac{C_{n}}{(!+i)^{n}}}$

$\mathrm{B}_{\mathrm{n}} \quad$ : Benefits realized in rupees per ha per annum (1-20 Years) 
$\mathrm{C}_{\mathrm{n}}$ : Costs incurred in rupees per ha per annum $(0,1-20$ Years $)$

n : Number of years of investment considered (0,1- 20 years)

i : Discount Rate (12 Per Cent)

\section{Net Present Value (NPV)}

This means the present value of the net benefits, obtained by deducting the total discounted cost stream from the total discounted stream of returns.

The positive NPV indicates worthiness of investment in Neem Plantations. This is simply the net present worth of cash flow stream.

$N P V=\sum_{i=1}^{n} \frac{B n-C n}{(1+i)^{n}}$

$\mathrm{B}_{\mathrm{n}}=$ Benefits realized in rupees per ha per annum

$\mathrm{C}_{\mathrm{n}}=$ Costs incurred in rupees per ha per annum

$\mathrm{n}=$ Number of years of investment

$\mathrm{i}=$ Discount rate. Here, the 12 per cent Discount rate was used for the study and the discounted benefits and costs were estimated

\section{Internal Rate of Return (IRR)}

The internal rate of return is the rate of discount at which NPV is zero. It is calculated by using following formula

$$
I R R=\sum_{i=1}^{N} \frac{\left(B_{\mathrm{t}}-C_{\mathrm{t}}\right)}{(1+r)^{t}}-I=0
$$

If IRR is greater than prevailing rate of interest or the cut off rate, the investment is considered to be financially feasible and economically a viable enterprise.

\section{Factors influencing neem seed collection}

Neem seed collection activity was performed by almost all age groups in the study area. One could assess the competition too while collecting the seeds. In this respect, something is influencing all the farmers to collect the Neem seeds and hence the study has aimed at assessing the factors influencing Neem seed collection. For that purpose, a Cobb-Douglass Production function was used to assess the factors influencing the quantity of Neem seeds collected by the households and also their relative influence.

The production function was estimated using Ordinary Least Square (OLS) method. The estimated regression coefficient values were tested for statistical significance at 10 per cent, five per cent and one per cent level.

The Cobb-Douglas production function was fitted for finding the factors influencing the collection of neem seeds by the households. The production function of the following form was used in the research.

$\mathrm{Y}=\mathrm{a} \mathrm{X}_{1}{ }^{\mathrm{b} 1} \mathrm{X}_{2}^{\mathrm{b} 2} \mathrm{X}_{3}^{\mathrm{b} 3} \mathrm{X}_{4}{ }^{\mathrm{b} 4} \mathrm{U}_{\mathrm{i}} \rightarrow 1$

The Cobb-Douglas production function specified in the equation 1 is expressed in the estimable form of equation (Production Function)

$\ln \mathrm{y}=\ln \mathrm{a}+\mathrm{b}_{1} \ln \mathrm{X}_{1}+\mathrm{b}_{2} \ln \mathrm{X}_{2}+\mathrm{b}_{3} \ln \mathrm{X}_{3}+\mathrm{b}_{4}$ $\ln X_{4}+b_{5} \ln X_{5}+\mu_{i} \rightarrow 2$

Where,

$\mathrm{Y}=$ Quantity of Neem seeds Collected by the Seed Collectors,

$\mathrm{X}_{1}=$ Age of the Seed Collector in Years

$\mathrm{X}_{2}=$ Size of the Family of the Neem Seed Collector in Numbers 
$\mathrm{X}_{3}=$ Distance Travelled by the Neem Seed Collector for the Collection of Neem Seeds in Kilometers

$\mathrm{X}_{4}=$ Time taken by the Neem Seed Collector for the Collection of seeds in Hours

$\mathrm{X}_{5}=$ Sale Price per $\mathrm{kg}$ of Neem Seeds in Rupees

b1, b2, b3, b4, b5 are the regression coefficients to be estimated.

$\mu_{\mathrm{i}}=$ Error Term. Besides this functional form of estimable equation, some factors may be priority to the farmers or the seed collectors and some of them may be less priority and hence ranking of these factors were also attempted by using Garett's Scoring Technique.

\section{Results and Discussion}

Neem and its value added products are great in demand as the consumers of Neem based products are becoming more health consciousness in the urban settings. In this respect, many firms have entered into the business of dealing with Neem based products and there exists a great demand for the Neem products and hence the farmers have started cultivating the Neem plantations in their farm holdings in recent years and hence effort has been taken to assess the area under Neem plantations. Among the 37 districts in Tamil Nadu, highest area under Neem plantations are visible only in Virudhunagar and Thoothukkudi Districts of Southern Tamil Nadu and hence this study was taken up in Southern Tamil Nadu focusing Virudhunagar District..

\section{Yield of neem plantations}

Neem not only provide the rich canopy cover and provide shelter to the common publicThe yield of Neem plantations under different age classes were arrived at and the details are presented in Table 2.

The Neem trees starts bearing from the age of three years and goes on yielding fruits every year. The fruit yield per tree is found to be increasing and it stabilizes during the age of 20 to 25 years. On an average, a Neem tree is capable of yielding around $58 \mathrm{Kgs}$. per annum and the yield per ha is found to be 11.75 tonnes of seeds (Table 2). 50 per cent of the yield is able to be achieved during the age group of 16-20 years. However, under proper maintenance with need based resources like water and protection from pest related issue, one could expect higher yield up to 40 years.

During the age of three to five years, the average yield is found to be only 3 per cent. Whereas, the age group of 6 to 10 years could provide only 10 per cent of the total yield that could be realizable up to 20 years of the Neem plantations.

\section{Economic incentives associated with the neem plantations}

Before planting an annual crop or perennial crop in the farm land, a farmer would be interested in analyzing the benefits that are accruing from it.

Its comparative profit relative to the existing system of agriculture and its suitability to the soil type in the farm. Information on costs incurred over years for the establishment and maintenance of Neem plantations and the returns realized over years will serve as an incentive to the farmers for making the choice.

The costs incurred and returns realized over years are discussed under the heads of Establishment Cost, Maintenance Cost, Cost of Production and Returns realized from Neem plantations. 


\section{Establishment cost}

Establishment cost sometimes referred to as fixed cost in Forest plantations which is incurred during the time of establishment of tree crops. The establishment costs included were Preparation of land, digging of pits, formation of irrigation channels, cost of filling of pits, Manuring, planting and basin formation, cost of irrigation, land taxes and cess etc. These details are analyzed and the results are presented in Table 3.

The Establishment Cost per ha for establishing a Neem Plantation is arrived at Rs. 13731/which includes land preparation, Cost of filling of pits, Manuring, Planting and Basin formation and Land Preparation alone consumed around 28 per cent of the total establishment cost. Among these, cost of seedling alone consumed around 19 per cent of it followed by cost of filling of pits and cost of irrigation have consumed almost equal in share. Since the cost of seedlings are left with the farmer at free of cost, he has been motivated to plant it in their field. After the establishment of the Neem plantations, it has to be maintained properly so as to draw the benefits in future.

\section{Maintenance cost for neem plantations}

Any production activity consumes some maintenance expenditures. Regular maintenance of any plantation will bring good growth and productivity. The maintenance activity in Neem plantations are Cost of Irrigation, Gap filling, Pruning and Basin formation, Manures and Manuring and Miscellaneous cost. These details had been generated for 20 years period by conducting inquiry with the farmer regarding the annual maintenance incurred and likely to be incurred over years for different activity. The data under maintenance were analysed and the details are presented in Table 4.
Table 4 outlined the costs on maintenance activities incurred for Neem plantations. Total Maintenance cost incurred for a period of 20 years was arrived at Rs. 1.89 lakhs with an average annual maintenance cost of Rs. 9460 per ha. Among the maintenance costs, Cost of irrigation found to be bit higher followed by miscellaneous expenses towards maintenance which are respectively accounted for 29.77 per cent and 25.90 per cent.

\section{Harvest and post-harvest expenses}

Besides, the farmer is also incurring the Harvesting and Post-Harvest expenditures and hence these details were analysed and the results are presented in Table 5.

Table 5 revealed that the harvest and postharvest expenses incurred by the farmer in respect of Neem plantations were arrived at Rs. 24069 per annum. The post-harvest expenses incurred by the farmer were cost of seed collection, drying, cleaning and packing. At the end of rotation period, cutting, sizing and loading of timber is practiced by the farmers. Among these, the cutting, sizing and loading of timber alone are accounted for Rs. $17125 /$ - which is accounted for 71 per cent to the total harvest and post-harvest expenses. Other two expenses consume almost similar cost which are accounted for 15 per cent and 14 per cent respectively for seed collection, drying and cleaning activities to supply the quality seeds to the traders. Already we have seen the details of different sources of income generation.

\section{Revenue generated from neem plantations in the farm holdings}

From the activity of Neem establishment and maintenance over years, the details of income generation per annum are analysed and the details are analysed and the results are presented in Table 6. 
A total income of 124 lakhs was able to be received from the Neem plantations per ha of 20 year rotation period. From that the farm household is able to secure an annual income of Rs. 6.23 lakhs. It is a considerable level of income to the rural folks in the district (Table 6). Among the total income, seed collection from Neem plantations have generated an income of 71 per cent followed by timber extraction activity consumed 29 per cent to the total income generation from the Neem plantations in the farm holdings.

\section{Economic appraisal of neem plantations}

Economic incentives associated with the Neem plantations established in the farm holdings were appraised by using the economic appraisal tools like Net Present Value (NPV), Benefit Cost Ratio (BCR), and the Internal Rate of Return (IRR). The analysis was made by using 12 per cent discount rate which is the normal lending rate for agricultural and other allied enterprises by the commercial banks. Using the 12 per cent discount rate, the analysis was made and the details of results are presented in Table 7.

The Economic Appraisal tools have highlighted that the Neem plantations are capable of generating higher income. This level of income is incomparable in respect of any other tree crops established under agroforestry situation because of less maintenance and left with not much care.

The plantation has generated a Benefit Cost Ratio of 19.56 indicated that for a rupee of investment, the plantation is able to generate Rs. 18.56 as net income from one ha of plantation. The Net Present Value is another appraisal tool which has explained that the Neem Plantations are able to generate around 20.95 lakhs in present value terms and the Internal Rate of Return was arrived at 97 per cent. Even under severe drought and risk related issues, the plantation is capable of generating highest profit and hence the farmers can take up such economic incentive based plantations.

\section{Factors influencing neem seed collection}

The quantity of Neem seed collected was influenced by several factors which is either positively contributing and few are negatively contributing to the quantity. In this circumstance which is the variables are significantly contributing to the quantity collected is of much important and hence a Cobb-Douglass production function was used to analyse the most correlated variables. These details are analysed and the results are presented in Table 8.

The results of Multiple Regression Equation tells that the quantity of Neem Seed collected depends directly on Size of the Family in Numbers, Time taken for Neem Seed collection in Hours, Price per $\mathrm{kg}$ of Neem Seed in Rupees and Age of the household member. The results of the Cobb-Douglass production function revealed that the Coefficient of Multiple Determination $\left(\mathrm{R}^{2}\right)$ is found to be 0.63 implied that the variables incorporated to the production function has contributed to the level of 63 per cent (Table 8). The remaining are unknown effects or unknown variables.

In respect of Age of the household member (X1), when one per cent of age advances than the mean level, the quantity of Neem seed collection started decreasing to the tune of 0.32 per cent keeping all other variables at their mean level. This variable is found to be significant at one per cent level outlined that the family member is showing disinterest in seed collection when their age advances by one year or more. 
Table.1 Details of samples selected for the study

\begin{tabular}{|c|c|c|c|c|c|}
\hline $\begin{array}{c}\text { Sl. } \\
\text { No }\end{array}$ & $\begin{array}{c}\text { Name of the } \\
\text { Block }\end{array}$ & $\begin{array}{c}\text { Number of } \\
\text { Neem Farmers }\end{array}$ & $\begin{array}{c}\text { Number of } \\
\text { Farmers } \\
\text { Selected }\end{array}$ & $\begin{array}{c}\text { Number of Seed } \\
\text { Collectors } \\
\text { Selected }\end{array}$ & $\begin{array}{c}\text { Total } \\
\text { Samples }\end{array}$ \\
\hline $\mathbf{0 1}$ & Sivakasi & 30 & 03 & 20 & 23 \\
\hline $\mathbf{0 2}$ & Vembakottai & 36 & 04 & 15 & 19 \\
\hline $\mathbf{0 3}$ & Virudhunagar & 46 & 05 & 20 & 25 \\
\hline $\mathbf{0 4}$ & Sathur & 27 & 03 & 15 & 18 \\
\hline $\mathbf{0 5}$ & Kaariapatti & 49 & 05 & 10 & 15 \\
\hline & Total & $\mathbf{1 8 8}$ & $\mathbf{2 0}$ & $\mathbf{8 0}$ & $\mathbf{1 0 0}$ \\
\hline
\end{tabular}

Table.2 Yield of neem plantations

\begin{tabular}{|c|c|c|c|c|}
\hline $\begin{array}{c}\text { Sl. } \\
\text { No }\end{array}$ & $\begin{array}{c}\text { Age of the Neem } \\
\text { Plantations in } \\
\text { Years }\end{array}$ & $\begin{array}{c}\text { Average Yield of } \\
\text { Fruits in Kgs per } \\
\text { Neem Tree* }\end{array}$ & $\begin{array}{c}\text { Average Yield of } \\
\text { Fruits in Kgs per } \\
\text { Ha }\end{array}$ & $\begin{array}{c}\text { Percentage to } \\
\text { Total Yield }\end{array}$ \\
\hline $\mathbf{0 1}$ & $03-05$ & 06.800 & 1360.000 & 2.89 \\
\hline $\mathbf{0 2}$ & $06-10$ & 24.100 & 4820.000 & 10.25 \\
\hline $\mathbf{0 3}$ & $11-15$ & 86.000 & 17200.000 & 36.61 \\
\hline $\mathbf{0 4}$ & $16-20$ & 118.000 & 23600.000 & 50.25 \\
\hline & Total Yield & 234.900 & 46980.000 & 100.00 \\
\hline & Mean & 58.725 & 11745.000 & \\
\hline
\end{tabular}

(*Primary Survey: Based on Recollection of Past Facts on Yield of Neem Tree)

Table.3 Establishment cost for neem plantations

\begin{tabular}{|c|c|c|c|}
\hline Sl. No & Particulars of Cost & Amount in Rupees per Ha & Percentage to Total \\
\hline $\mathbf{0 1}$ & Land Preparation & 3856.50 & 28.09 \\
\hline $\mathbf{0 2}$ & Digging of Pits & 2258.27 & 16.45 \\
\hline $\mathbf{0 3}$ & Cost of Seedlings (Including & 2608.00 & 18.99 \\
\hline $\mathbf{0 3}$ & Transportation) & 1356.25 & 9.88 \\
\hline $\mathbf{0 4}$ & $\begin{array}{c}\text { Cormation of Irrigation Channels } \\
\text { Planting and Basin Formation }\end{array}$ & 1753.60 & 12.77 \\
\hline $\mathbf{0 5}$ & Cost of Irrigation & 1738.65 & 12.66 \\
\hline $\mathbf{0 6}$ & Land Taxes and Cess & 160.00 & 01.17 \\
\hline $\mathbf{0 7}$ & Total Establishment Cost & $\mathbf{1 3 7 3 1 . 2 7}$ & $\mathbf{1 0 0 . 0 0}$ \\
\hline
\end{tabular}


Table.4 Maintenance cost involved in neem plantations per annum for 20 year rotation

\begin{tabular}{|c|c|c|c|c|c|}
\hline Year & $\begin{array}{c}\text { Irrigation } \\
\text { Cost }\end{array}$ & $\begin{array}{c}\text { Gap Filling, } \\
\text { Pruning \& Basin } \\
\text { Formation }\end{array}$ & $\begin{array}{c}\text { Manures } \\
\text { and } \\
\text { Manuring }\end{array}$ & $\begin{array}{c}\text { Miscellaneous } \\
\text { Cost }\end{array}$ & $\begin{array}{c}\text { Total } \\
\text { Maintenance } \\
\text { Cost }\end{array}$ \\
\hline Total & 56315.00 & 45960.00 & 37919.00 & 49000.00 & 189194.00 \\
\hline Mean & 2815.75 & 2298.00 & 1895.95 & 2450.00 & 9459.70 \\
\hline $\begin{array}{c}\text { \% to } \\
\text { Total }\end{array}$ & 29.77 & 24.29 & 20.04 & 25.90 & 100.00 \\
\hline
\end{tabular}

Table.5 Harvesting and post-harvest expenditures for 20 years

\begin{tabular}{|c|c|c|c|c|}
\hline Year & $\begin{array}{c}\text { Cost of Seed } \\
\text { Collection }\end{array}$ & $\begin{array}{c}\text { Drying Cleaning and } \\
\text { Packing }\end{array}$ & $\begin{array}{c}\text { Cutting Sizing and } \\
\text { Loading of Timber } \\
\text { Charges }\end{array}$ & Total Cost \\
\hline Total & 64060.00 & 60400.00 & 68500.00 & 192960.00 \\
\hline Mean & 3588.89 & 3355.56 & 17125.00 & 24069.45 \\
\hline$\%$ & $\mathbf{1 4 . 9 1}$ & $\mathbf{1 3 . 9 4}$ & $\mathbf{7 1 . 1 5}$ & $\mathbf{1 0 0 . 0 0}$ \\
\hline
\end{tabular}

Table.6 Sources of Revenue Generated from Neem Plantations in the Farm Holdings for 20 years

\begin{tabular}{|c|c|c|c|c|}
\hline Year & $\begin{array}{c}\text { Sale of Neem } \\
\text { Seeds in Rs }\end{array}$ & $\begin{array}{c}\text { Sale of Fuel } \\
\text { Wood in Rs }\end{array}$ & $\begin{array}{c}\text { Sale of Timber / } \\
\text { Logs }\end{array}$ & $\begin{array}{c}\text { Total } \\
\text { Revenue in } \\
\text { Rs. }\end{array}$ \\
\hline Total Rupees & 8822840.00 & 45204.00 & 3588000.00 & 12456044.00 \\
\hline Mean & 441142.00 & 2260.20 & 179400.00 & 622802.20 \\
\hline$\%$ & 70.83 & 00.36 & 28.81 & 100.00 \\
\hline
\end{tabular}

Table.7 Economic appraisal of neem plantations

\begin{tabular}{|c|c|c|}
\hline Sl. No & Method of Appraisal & Amount (in Rs) \\
\hline $\mathbf{0 1}$ & Gross Income Realized per Annum in Rupees & 622802.20 \\
\hline $\mathbf{0 2}$ & Benefit - Cost Ratio & 19.56 \\
\hline $\mathbf{0 3}$ & Net Present Value in Rupees & 2094786.00 \\
\hline $\mathbf{0 4}$ & Internal Rate of Return (in Per Cent) & 97.13 \\
\hline $\mathbf{0 5}$ & Total Cost Incurred in Rupees per Ha per Annum & 33910.97 \\
\hline $\mathbf{0 6}$ & Average Quantity of Seed Collected in Kgs & 11745.000 \\
\hline $\mathbf{0 7}$ & Cost of Collection of Seed per Kg in Rupees & 02.89 \\
\hline $\mathbf{0 8}$ & Sale of Neem Seeds in Rupees per Kg & 38.00 \\
\hline $\mathbf{0 9}$ & Profit per Kg Earned by the Seed Collectors in & 35.11 \\
\hline
\end{tabular}


Table.8 Factors influencing neem seed collection - a functional analysis

\begin{tabular}{|c|c|c|c|c|}
\hline Particulars & Coefficient & Standard Error & 't' Statistics & P-Value \\
\hline Intercept & 3.789592 & 0.576256 & 6.57623 & $6 \mathrm{E}-09$ \\
\hline Age in Years & -0.31744 & 0.110661 & -2.86856 & $0.00537 * * *$ \\
\hline $\begin{array}{c}\text { Size of the Family in Numbers } \\
\text { Distance Travelled for Neem } \\
\text { Seed collection in Kms. }\end{array}$ & 0.122418 & 0.035459 & 3.45234 & $0.000922^{*} * *$ \\
\hline $\begin{array}{c}\text { Time taken for Neem Seed } \\
\text { Collection in Hours }\end{array}$ & 0.012582 & 0.017369 & 0.724362 & 0.471127 \\
\hline $\begin{array}{c}\text { Price per kg of Neem Seed in } \\
\text { Rupees }\end{array}$ & 0.633548 & 0.114759 & 5.520697 & $4.77 \mathrm{E}-07 * * *$ \\
\hline $\mathbf{R}^{\mathbf{2}}$ & 0.6277 & \multicolumn{2}{|c|}{ ' $\mathrm{F}$ ' Value } & 24.95 \\
\hline
\end{tabular}

(*** Indicates One Per Cent Level of Significance and * Indicates 10 Per Cent Level of Significance)

Size of the family is another important variable which is also found to be significant at one per cent level revealed that an increase in one per cent of size of family member involved in collection of Neem seed contributed an increase in the quantity of Neem seed collected to the tune of 0.12 per cent keeping all other variables at their mean level. Time taken for Neem Seed collection in Kilometres is another important variable which is also significant at ten per cent level of significance revealed that one per cent increase in the time taken for collection of seeds is found to increase 0.048 per cent increase in the quantity of Neem seed collection keeping all other variables at their mean level.

Price per $\mathrm{kg}$ of Neem seed is another important decision variable which is also found to be significant at one per cent level. One per cent increase in the price of Neem seed in the market motivates the family member to collect 0.63 per cent of the total collection of Neem seeds keeping all other variables at constant level. On summing up the coefficient of the influencing variables incorporated in the study, the coefficient was arrived at 0.50 which indicated that the production function fitted showed a decreasing return to scale (Table 8 ). The ' $F$ '
Value generated was also found to be 24.95 indicated that the function fitted was found to be the best fit. In general it is inferred that the Neem seed collection is facing a decrease in quantity year after year due to the absence of number of trees in the farm lands and in the common lands across the district because of the heavy demand for fuel wood in the Brick kiln industries and household timber requirements.

\section{Summary}

Neem plantations in Southern Tamil Nadu found to be economically a viable and most profitable enterprise according to the economic appraisal tools. The farm households who depend on the Neem plantations were able to generate on an average around six lakhs as gross income per annum.

It is a source of considerable earning. Since Neem seeds have higher demand in the market, the Neem plantations and its area should be increased. In recent times, the area under Neem plantations found to be decreasing and hence effort has to be taken to enhance the area under Neem plantations either through mass promotional campaign with incentives to grow the Neem plantations 
in the farm lands or time bound input subsidy has to be given to the farmer for promotion of area under Neem plantations.

\section{References}

Lokanadhan K, Subbalakshmi, P Muthukrishnan, and S Jeyaraman. 2012. "Neem Products and their Agricultural Applications." Journal of Biopesticides, 5:72.

Sekhar, C., (1995) "Demand for and Supply of PUlpwood in Tamil Nadu", (Unpublished Ph.D. Thesis in Forestry, submitted to College of Forestry, Tamil Nadu Agricultural University, Coimbatore)

Singh, Ritambhara, MR Prajapati, and Jemish Savani. 2017. "Economics of Production of Drumstick (Moringa olifera) in Vadodara District of Gujarat." International Journal of Advanced Biological Research, 7 (2):322-328.

https://www.neemfoundation.org/events/world -neem-conference/

http://worldneemorganisation.org/Gallery

\section{How to cite this article:}

Divakaran, A., C. Sekhar and Balajji, P. 2019. Factors Influencing Establishment of Neem Plantations in Southern Tamil Nadu. Int.J.Curr.Microbiol.App.Sci. 8(11): 1693-1703. doi: https://doi.org/10.20546/ijcmas.2019.811.197 